\title{
A Report on Faculty Perceptions of Students' Information Literacy Competencies in Journalism and Mass Communication Programs: The ACEJMC Survey
}

\author{
Annmarie B. Singh
}

This article presents the results of a survey done of the faculty of programs fully accredited by the Accrediting Council on Education in Journalism and Mass Communications (ACEJMC) in 2002-2003. The purpose of the survey was to assess the faculties' perceptions of their students' information literacy skills as defined by the ACRL standards adopted in 2000. Faculty reported that most of their graduate students met the $A C R L$ criteria for information literacy, but only some of their undergraduate students could be considered information literate by these standards. Faculty also reported consistent improvement in their students' research process after receiving library instruction.

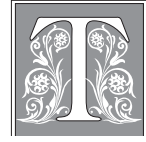

hroughout its history and in the current discussion of the status of journalism and mass communication (JMC) education in higher education, emphasis on the student acquiring a bread th of knowledge coupled with practical journalistic skills has been consistent. The Accrediting Council on Education in Journalism and Mass Communications (ACEJMC), which grants accreditation to such programs, adopted revised standards in September of 2003 that delineate nine standards with indicators and examples of evidence for each by which JMC programs will be evaluated for accreditation as of September 2004. In standard \#2 on curriculum and instruction, the ACEJMC identifies critical thinking and the ability to "conduct research and evaluate information by methods appropriate for the communications professions in which they work" as professional competencies. ${ }^{1}$ Additionally, the ACEJMC standards for accreditation include the provision of adequate library and information resources as an indicator of the administration's efforts to maintain and fulfill the program's mission (Standard 7: Resources, Facilities, and Equipment). ${ }^{2}$

Seventeen years prior, in the 1987 report, Planning for Curricular Change: A Report on the Project on the Future of Journalism and Mass Communication Education,

Annmarie B. Singh is the Communication Studies Librarian at Hofstra University; e-mail: librfabs@hofstra. edu. 
the authors stated that information gathering was one of five basic competencies journalism educators agreed their graduates should have. ${ }^{3}$ In a discussion of the debate over whether journalism should be approached as an academic discipline, Betty Medsger, in her 1996 report, Winds of Change: Challenges Confronting Journalism Education, stated that the debate itself reveals:

\begin{abstract}
a lack of understanding of the intellectual nature of the skills of journalism...that these skills fall under the category of 'intellectual,'... [the skills of] research, critical thinking, organization of material and clear expression...the key skills the university tries, but often fails, to teach all students as essential parts of their liberal education." ${ }^{4}$
\end{abstract}

These skills have evolved in higher education as the notion of information literacy (a term that has been in the vernacular of higher education since 1974). ${ }^{5}$ In January 2000, information literacy became formalized in higher education with the endorsement by the American Association for Higher Education of the standards established by the Task Force on Information Literacy Competency Standards of the Association of College and Research Libraries (ACRL). In defining information literacy, the task force made the statement, "The sheer abundance of information will not in itself create a more informed citizenry without a complimentary cluster of abilities necessary to use information effectively." ${ }^{6}$ The task force delineated five standards, each with extensive performance indicators and outcomes. In defining information literacy, the task force stated that an information-literate person would be a person who is able to:

- Determine the extent of information needed

- Access the needed information effectively and efficiently

- Evaluate information and its sources critically
- Incorporate selected information into one's knowledge base

- Use information effectively to accomplish a specific purpose

- Understand the economic, legal, and social issues surrounding the use of information, and access and use information ethically and legally ${ }^{7}$

The assumption is that through achievement of these abilities, the citizenry will become effective information users and "life-long learners." ${ }^{8}$ Given the striking parallel between these abilities and the tools professionals working in JMC use every day, and acknowledging the directives from various sources that research competency be expected of, and appropriate training be provided for, students in JMC programs, a survey was done to assess how the information literacy skills of this student population are perceived by their faculty and how library instruction is being provided and integrated into the curriculum as a means of building research competencies.

\section{Research Rationale}

In order to assess faculty perceptions of JMC students' information literacy skills and the rate and impact of library instruction in JMC curricula, a survey was created to appraise the following:

- How frequently do faculty teaching students in JMC programs give assignments requiring library research?

- How frequently do faculty teaching students in JMC programs integrate library instruction into their courses?

- What do faculty report is the impact library instruction has on the research skills of JMC students?

- What research skills and practices do faculty report students in these programs possess?

- How do faculty of students in JMC programs perceive their students' information literacy skills as defined by the ACRL standards?

To answer these questions, the fulltime faculties of all programs holding full accreditation by the ACEJMC during 
2002-2003 were surveyed. This article is a descriptive report on the results of that survey and presents the data for undergraduate and graduate students in four sections: library instruction, impact of library instruction, information literacy assessment, and student research skills and practices.

\section{Methodology}

In May 2002, 1,908 surveys were sent to full-time faculty teaching in programs holding full accreditation by the ACEJMC. Programs and faculty were identified through the listing of accredited programs for 2002-2003 posted on the ACEJMC Web site. A database of programs and faculty was created based on the listing and a mailing was generated, with each faculty member being sent a letter of introduction and explanation, a survey, and a postage-paid return envelope. Faculties were asked to return the survey by November 2002. Four hundred and twenty-five usable surveys were received resulting in a 22.3 percent return rate. The data were entered into the Statistical Package for the Social Sciences (SPSS, version 11) software for analysis. This article reports on the responses to seventeen of the twenty-six questions posed to faculty, the content of which would be of interest to the audience of this publication: academic and special librarians.

\section{Survey Instrument}

The survey instrument was a questionnaire consisting of twenty-six items that were measured using a Likert-type scale. The range of responses on the majority of the items were: every/all, most, some, few, none, N/A, cannot judge; excellent, strong, adequate, poor, N/A, cannot judge. One question required a response of agree, disagree, or do not know, and one question required a response of either improved, made no difference in, or confused. There also was one open-ended question to which faculty could write in any information-seeking skills they believed a student being prepared to work in mass media should have (the content analysis of which is not included here).

The validity of the inferences made about the information literacy competency of undergraduates and their research skills is impacted by the fact that the survey questions did not allow faculty to clarify the level (freshmen, sophomore, etc.) of the undergraduate student. It can be assumed that the level of the undergraduate student could have an effect on his or her research abilities (upperclassmen would be more capable than freshmen) and that effect is not accounted for here. Therefore, the results apply to faculty who teach undergraduates on all levels. Also, it is reasonable to assume that some faculty would teach exclusively technical courses and would not be giving assignments requiring library research or making library instruction a regular part of their courses. To control this confound, faculties surveyed were given the option to respond "cannot judge" and "N/A" to questions, enabling faculty for whom questions were not relevant to exclude themselves.

External validity for this study is strong, as it is reasonable to generalize these results to the experiences and practices of faculty teaching undergraduates on all levels and graduate students in other JMC programs not accredited by the ACEJMC. JMC programs typically include technical and theoretical courses. Internal consistency for the items on this instrument is adequate to high for the four subscales into which the instrument has been divided. This is demonstrated in table 1.

\section{Findings}

\section{Library Instruction}

Faculties were asked to report the frequency with which they gave assignments requiring library research in their courses and how often they made library instruction a regular part of the courses they taught. Four hundred and twelve (96.9\%; $\mathrm{n}=425$ ) faculty teaching undergraduates responded to the question about assign- 


\begin{tabular}{|c|c|c|c|c|c|c|c|}
\hline & & Reli & $\begin{array}{r}\text { TABLE } \\
\text { bility Analy }\end{array}$ & s of Scal & & & \\
\hline & $\begin{array}{r}\text { Libra } \\
\mathrm{S}\end{array}$ & $\begin{array}{l}\text { y Instr. } \\
\text { ale }\end{array}$ & $\begin{array}{l}\text { Impact of } \\
\text { Lib. Instr. }\end{array}$ & $\begin{array}{l}\text { Info. I } \\
\text { Assess }\end{array}$ & $\begin{array}{l}\text { iteracy } \\
\text { Scale }\end{array}$ & $\begin{array}{r}\text { Stud } \\
\text { Skills/P }\end{array}$ & $\begin{array}{l}\text { nt Res. } \\
\text { act. Scale }\end{array}$ \\
\hline & $\begin{array}{l}\text { Under } \\
\text { Grad. }\end{array}$ & Grad. & $\begin{array}{c}\text { Under } \\
\text { Grad. \& } \\
\text { Grad. } \\
\text { Comparison }\end{array}$ & $\begin{array}{l}\text { Under } \\
\text { Grad. }\end{array}$ & Grad. & $\begin{array}{l}\text { Under } \\
\text { Grad. }\end{array}$ & Grad. \\
\hline $\begin{array}{l}\# \text { of } \\
\text { Variables }\end{array}$ & 3 & 3 & 2 & 2 & 2 & 13 & 13 \\
\hline $\begin{array}{l}\text { Mean Mean } \\
\text { for Items }\end{array}$ & 2.4101 & 2.5046 & 2.382 & 3.0673 & 3.0237 & 3.0283 & 2.3739 \\
\hline $\begin{array}{l}\text { Mean } \\
\text { Variance } \\
\text { for Items }\end{array}$ & 1.262 & 2.5063 & 1.9684 & 0.7842 & 2.3089 & 1.1857 & 1.0228 \\
\hline $\begin{array}{l}\text { Inter-item } \\
\text { Covariance }\end{array}$ & 0.3234 & 0.7426 & 0.9698 & 0.5127 & 1.9826 & 0.4149 & 0.3131 \\
\hline $\begin{array}{l}\text { Inter-item } \\
\text { Correlation }\end{array}$ & 0.2276 & 0.208 & 0.4941 & 0.6659 & 0.8821 & 0.3628 & 0.3171 \\
\hline $\begin{array}{l}\text { Mean for } \\
\text { Scale }\end{array}$ & 7.2302 & 7.5138 & 4.764 & 6.1346 & 6.0475 & 39.3682 & 30.8606 \\
\hline $\begin{array}{l}\text { Variance for } \\
\text { Scale }\end{array}$ & 5.7264 & 11.9745 & 5.8766 & 2.5939 & 8.5832 & 80.1334 & 62.1344 \\
\hline $\begin{array}{l}\text { Standard } \\
\text { Dev. for } \\
\text { Scale }\end{array}$ & 2.393 & 3.4604 & 2.4242 & 1.6106 & 2.9297 & 8.9517 & 7.8825 \\
\hline $\begin{array}{l}\text { Reliability } \\
\text { Coefficients } \\
\text { on: }\end{array}$ & & ems & 2 Items & 2 It & ms & 13 & tems \\
\hline $\begin{array}{l}\text { Cronbach's } \\
\text { Alpha }\end{array}$ & 0.5083 & 0.5582 & 0.6601 & 0.7906 & 0.924 & 0.8749 & 0.8515 \\
\hline $\begin{array}{l}\text { Standardized } \\
\text { Item Alpha }\end{array}$ & 0.4693 & 0.4406 & 0.6614 & 0.7995 & 0.9373 & 0.8810 & 0.8579 \\
\hline No. of Cases & 391 & 327 & 356 & 416 & 358 & 402 & 287 \\
\hline
\end{tabular}

ments requiring library research, with $137(33.3 \% ; n=412)$ reporting they made assignments requiring library research a regular part of every class they taught. Only ten $(2.4 \% ; n=412)$ stated none of their classes included assignments requiring library research. (See table 2.)

To the question about the frequency with which library instruction was made a regular part of the courses they taught, $408(96 \% ; n=425)$ faculty teaching under- graduates responded. Of those, thirty-five $(8.6 \% ; n=408)$ stated they made library instruction a regular part of every course they taught; $117(28.7 \%$; $=408)$ stated library instruction was not made a regular part of any of the courses they taught.

A cross-tabulation of these two questions showed a moderate positive correlation of $r=.477(\mathrm{Q}=.448)$. Four hundred and two $(94.6 \% ; n=425)$ faculty answered both questions and of that number, 133 
$(33.1 \% ; n=402)$ reported they made assignments requiring library research a regular part of every class they taught, yet only thirty-three of them $(24.8 \% ; n=$ 133) said they made library instruction a regular part of every class as well. Twenty four $(18 \% ; n=133)$ reported assignments requiring library research were a regular part of every course they taught, yet they did not make library instruction a regular part of any course they taught. Of the $101(25.1 \% ; n=402)$ who said they made assignments requiring library research a regular part of most of the courses they taught, only two $(2 \% ; n=101)$ said library instruction was a regular part of every course they taught, with the largest percentage of this group, 29.7 percent (30; $n=101$ ), reporting that regular library instruction was a part of some of the courses they taught. Of those ninety-four (23.3\%; $\mathrm{n}=402$ ) faculty who stated some of their courses regularly included assignments requiring library instruction, none made it a part of every course and the highest percentage of this group, 30.9 percent (29; $\mathrm{n}=94$ ), stated they made library instruction a regular part of only some of the courses they taught. (See table 3.)

The same two questions were posed to faculty teaching graduate courses. Three hundred and fifty-six $(83.8 \% ; n=425)$ faculty surveyed responded to the first question. As could be expected, a higher percentage of faculty reported making assignments requiring library research a regular part of the courses they taught to graduate students than for undergraduate students, with $210(59 \%$; $n=356)$ stating such assignments were a regular part of their graduate courses. Only six $(1.7 \% ; n=356)$ of these faculty reported assignments requiring library research were not a regular part of the graduate courses they taught. The second question on the frequency at which they made library instruction a regular part of their graduate courses got a response rate of 81 percent $(344 ; n=425)$. Only fifty $(14.5 \% ; \mathrm{n}=344)$ faculty members stated they made it a regular part of every course they taught, forty-seven $(94 \%$; $n=$ 50) of which also reported making library assignments a part of every course. The greatest number, seventy-five $(21.8 \%$; $\mathrm{n}=$ $344)$, reported they did not make library instruction a regular part of any of the courses they taught. Again, as with the undergraduate data, the cross-tabulation of these two questions showed a similar moderate positive correlation $(r$ $=.638 ; \mathrm{Q}=.634)$ as the greatest number of faculty reporting they made assignments requiring library research a part of every course they taught, also stated they did not make library instruction a part of any of the courses they taught (48; $23.6 \%$; $=203$ ).

TABLE 2

Frequency of Faculty Reporting on Research Assignments and Library Instruction: Undergraduate and Graduate $(\mathrm{N}=425)$

\begin{tabular}{|l|c|c|c|c|c|c|c|c|}
\hline \hline \multicolumn{2}{|c|}{ Research Assignments } & \multicolumn{2}{c|}{$\begin{array}{c}\text { Library } \\
\text { Instruction }\end{array}$} & \multicolumn{3}{c|}{ Standard Deviation } \\
\hline & Frequency/ \% No. & Frequency/ \% No. & \multicolumn{2}{c|}{ Res.Assgn } & \multicolumn{2}{c|}{ Lib.Instr. } \\
\hline & Ugrad & Grad & Ugrad & Grad & Ugrad & Grad & Ugrad & Grad \\
\hline Every & $137 / 33.3$ & $210 / 59$ & $35 / 8.6$ & $50 / 14.5$ & & & & \\
\hline Most & $104 / 25.2$ & $36 / 10.1$ & $64 / 15.7$ & $48 / 14$ & 1.198 & 2.055 & 1.393 & 1.782 \\
\hline Some & $97 / 23.5$ & $16 / 4.5$ & $87 / 21.3$ & $42 / 12.2$ & \multicolumn{4}{|c|}{ Mean } \\
\hline Few & $60 / 14.6$ & $10 / 2.8$ & $85 / 20.8$ & $45 / 13.1$ & \multicolumn{2}{|c|}{ Res.Assgn. } & Lib.Instr. \\
\hline None & $10 / 2.4$ & $6 / 1.7$ & $117 / 28.7$ & $75 / 21.8$ & Ugrad & Grad & Ugrad & Grad \\
\hline N/A & $4 / 1$ & $78 / 21.9$ & $20 / 4.9$ & $84 / 24.4$ & 2.31 & 2.44 & 3.6 & 3.87 \\
\hline
\end{tabular}




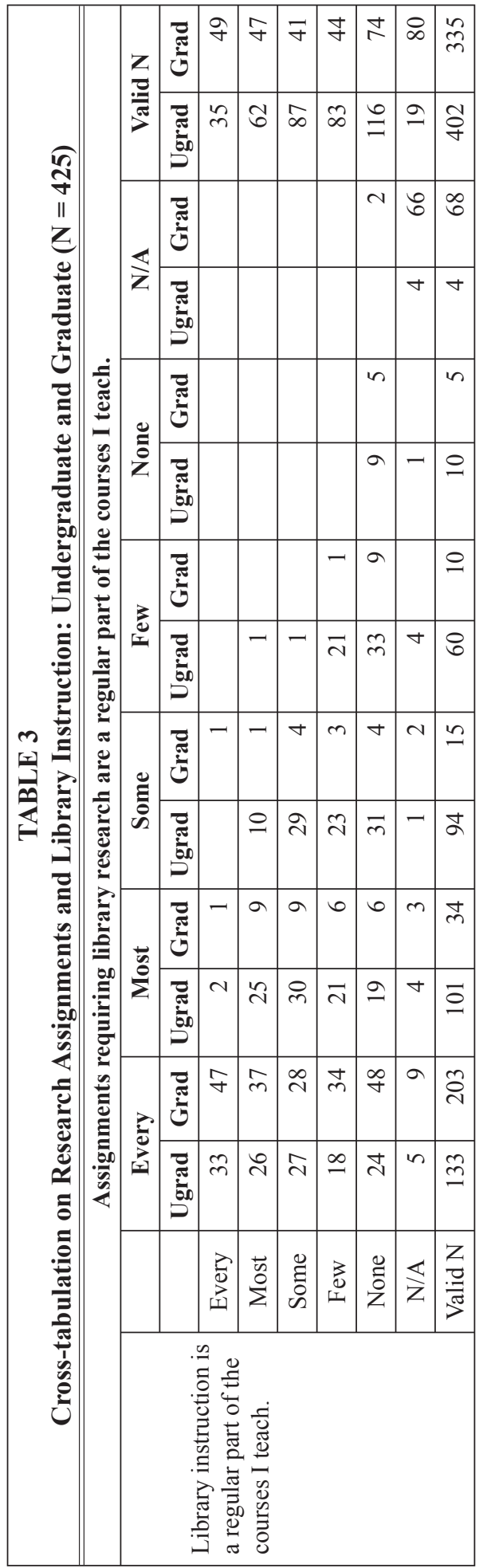

\section{Impact of Library Model on Frequency of} Library Instruction

To assess whether having a library liaison available for specialized curricular support influenced the rate at which faculty made library instruction a regular part of the courses they taught, faculty were asked to agree, disagree, or respond "do not know" to the following statement, "Our college/school/division/ department has a library liaison who acts as a subject specialist in support of our programs/courses." It was assumed that the faculty who agreed with this statement at the highest rate would be the same faculty who reported making library instruction a regular part of their courses at the highest rate. Four hundred and ten $(96.5 \% ; n=425)$ faculty members responded to this question, with 319 $(77.8 \% ; n=410)$ agreeing that this was the model employed by their institutions' library. (See table 4.)

A cross-tabulation showed that of those 397 faculty teaching undergraduates who answered the question on knowledge of their library's model and frequency of library instruction, $309(77.8 \% ; n=397)$ agreed their college/school/division/department had a library liaison available. Seventy-eight of these faculty $(25.2 \% ; n=309)$ stated they had a library liaison available and never made library instruction a regular part of the courses they taught. Less than half as many faculty $(31 ; 10 \% ; n=309)$ who agreed to the library liaison model stated they made instruction a part of every course they taught. (See table 5.) This was not the positive correlation anticipated by the author. There also was a positive correlation between not knowing if the library liaison model was used by the institution's library and the frequency with which library instruction was made a regular part of courses. As the rate of faculty reporting not knowing the model increased, the rate of not integrating library instruction into courses increased $(r=.164 ; \mathrm{Q}=.158)$. (See table 5.) A similar positive correlation occurred 
in the reported habits of the faculty when teaching graduate students (as agreement to the library liaison model increased, not integrating library instruction into courses increased). It appears that asking faculty not only if they are aware of the existence of a library liaison to their

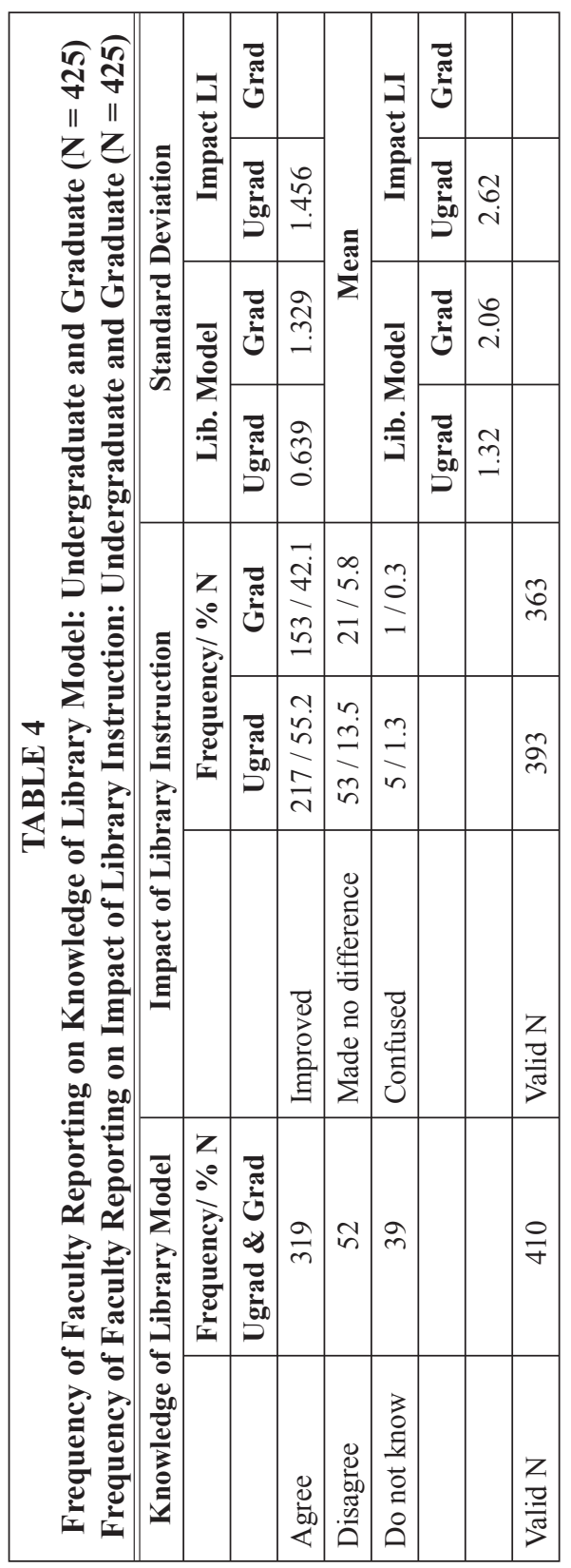

college/school/division/department, but whether this made a difference in their integrating library instruction into their courses and whether how they involved the library liaison in their curricular planning would produce more insight and is a viable area for future research.

\section{Impact of Library Instruction on Student Research}

To appraise the impact library instruction had on students' research processes, faculty were asked to report if library instruction improved, made no difference in, or confused their students' understanding of the research process. Three hundred and ninety-three $(92.5 \%$; $\mathrm{n}=425$ ) faculty teaching undergraduates responded, with over half $(217 ; 55.2 \%$; $n$ = 393) reporting their students' research processes improved after library instruction. Fifty-three $(13.5 \% ; n=393)$ reported library instruction made no difference in their students' research processes, and only five $(1.3 \% ; n=393)$ stated that their students' research processes were confused by library instruction. (See table 4.) For those faculty teaching graduate students, 153 of the 363 faculty $(42.1 \%$; $\mathrm{n}=363 ; 85.4 \% ; \mathrm{n}=425)$ responding to the question stated that library instruction improved their students' research processes, twenty-one $(5.8 \% ; \mathrm{n}=363$ ) reported that it made no difference, and only one $(.3 \% ; n=363)$ said it caused confusion.

A cross-tabulation of this question with the query on the frequency with which faculty made library instruction a regular part of the classes they taught (table 6) found that the greatest number reported library instruction was a part of every class they taught and that it improved their students' research process ( 40 or $12.5 \%$; $n=320$ ). Responses show that regardless of the frequency with which library instruction was made a regular part of courses, faculty consistently reported that it improved their students' research processes (147, or $45.9 \%$; $\mathrm{n}=320$ ). 


\begin{tabular}{|c|c|c|c|c|c|c|c|c|c|}
\hline \multirow{2}{*}{\multicolumn{10}{|c|}{$\begin{array}{c}\text { TABLE } 5 \\
\begin{array}{c}\text { Cross-tabulation on Faculty Knowledge of Library Model and Frequency of } \\
\text { Library Instruction: Undergraduate and Graduate }(\mathrm{N}=\mathbf{4 2 5})\end{array} \\
\begin{array}{c}\text { Our college/school/division/department has a library liaison who acts as a subject } \\
\text { specialist in support of our programs/courses. }\end{array}\end{array}$}} \\
\hline & & & & & & & & & \\
\hline \multirow{9}{*}{$\begin{array}{l}\text { Library } \\
\text { instruction } \\
\text { is a regular } \\
\text { part of the } \\
\text { courses I } \\
\text { teach. }\end{array}$} & & \multicolumn{2}{|c|}{ Agree } & \multicolumn{2}{|c|}{ Disagree } & \multicolumn{2}{|c|}{ Do Not Know } & \multicolumn{2}{|c|}{ Valid N } \\
\hline & & Ugrad & Grad & Ugrad & Grad & Ugrad & Grad & Ugrad & Grad \\
\hline & Every & 31 & 35 & 2 & 8 & & 4 & 33 & 47 \\
\hline & Most & 47 & 36 & 9 & 7 & 6 & 4 & 62 & 47 \\
\hline & Some & 73 & 33 & 7 & 5 & 5 & 3 & 85 & 41 \\
\hline & Few & 66 & 38 & 11 & 4 & 6 & 3 & 83 & 45 \\
\hline & None & 78 & 58 & 18 & 6 & 18 & 11 & 114 & 75 \\
\hline & N/A & 14 & 65 & 2 & 9 & 4 & 7 & 20 & 81 \\
\hline & $\begin{array}{l}\text { Valid } \\
\mathrm{N}\end{array}$ & 309 & 265 & 49 & 39 & 39 & 32 & 397 & 336 \\
\hline
\end{tabular}

\section{Student Research Skills and Practices}

Twelve statements were posed to faculty to gather their perceptions of students' skills in the areas of question formulation, critical thinking, information organization, research practices and processes, use of print reference sources, electronic database searching, World Wide Web searching, and information evaluation. (See table 7.)

The predominant response to these statements (33\% of all responses) from faculty teaching undergraduates was that some of their students had the abilities and knowledge listed. Interestingly, $148(35.7 \% ; n=415)$ faculty reported that few of their students understood that research is a strategic process and approached it as such. Similarly, 144 (34.8\%; $\mathrm{n}=414$ ) stated that few of their students knew that research methodologies varied and applied the appropriate method as necessary. These two items correlated significantly: $r=.588 ; \mathrm{Q}=.612$ for undergraduate responses; $r=.791 ; \mathrm{Q}=.702$ for graduate students. A cross-tabulation of the question on students' understanding of research as a strategic process with the question on frequency of library instruction showed that of the 403 (94.8\%; $\mathrm{n}=425$ ) faculty teaching undergraduates who responded to both statements, the highest number $(38 ; 9.4 \% ; n=403)$ stated only some of their students understood research is a strategic process and those thirty-eight faculty did not make library instruction a part of any of the courses they taught. The second highest number, thirty-seven $(9.2 \% ; n=403)$ stated that few of their students understood that research is a strategic process and library instruction was a regular part of few of their courses. (See table 8.)

Faculty teaching graduate students reported that most of their students possessed the abilities and knowledge questioned (46.2\% of all responses). One hundred and ninety-three $(65 \% ; n=297)$ stated most of their graduate students could conceptualize and formulate good questions. When considering the statements on their students' critical thinking skills and ability to apply analysis and original thought to create new information, $204(68.2 \%$; $\mathrm{n}=299)$ and $139(41.9 \%$; $\mathrm{n}=332)$, respectively, responded most (table 7).

\section{Information Literacy Assessment}

Faculty were presented with a section of the ACRL Task Force on Information Literacy Competency Standards that defines core competencies for information literacy and asked to respond to the state- 
ment, "Given these standards, I would say my students are information literate." Faculty then were asked to respond to the statement: "I would categorize the research skills of my students as..." and were given the options of excellent, strong, adequate, poor, n/a, and cannot judge. (See table 9.)

Four hundred and nineteen $(98.6 \%$; $\mathrm{n}$ $=425$ ) faculty teaching undergraduates responded to the first statement, with only sixteen $(3.8 \% ; \mathrm{n}=419)$ reporting they believed all of their students met the ACRL criteria. The highest number, 177 $(42.2 \% ; n=419)$, stated that some of their students met the ACRL criteria with ninety-eight $(23.4 \% ; n=419)$ responding that few of their students could be considered information literate according to these standards. Significantly, only three $(.7 \%$; $n=419)$ said none of their undergraduate students were information literate based on these measures.

Similarly, only one faculty member reported that none of his graduate students could be considered information literate according to these standards $(.3 \% ; \mathrm{n}=362)$. Thirty-three $(9.1 \% ; n=362)$ reported all of their graduate students met the ACRL standards, with the greatest number, $160(44.2 \%$; $\mathrm{n}=362$ ) stating that most of their students' were information literate according to these standards.

To the second statement on research skills, a total of 417 (98.1\%; $\mathrm{n}=425)$ faculty teaching undergraduates responded, with seven $(1.7 \%$; $\mathrm{n}=417)$ stating they believed the research skills of their students were excellent and 141 $(33.8 \% ; n=417)$ stating that they found their students' research skills to be poor. A cross-tabulation of the data on this question with the responses to the frequency of library instruction for undergraduate students showed that of the $406(95.5 \%$; $n=425)$ faculty who answered both questions, $136(33.5 \% ; n=406)$ stated their students' research skills were poor and of them 27.9 percent $(38 ; \mathrm{n}=$ 136) reported they did not make library instruction a regular part of any of their courses. Only 4.4 percent $(6 ; n=136)$ reported they made library instruction a part of every course. (See table 10.)

When asked to characterize the research skills of their graduate students, 371 faculty $(87.3 \%$; $n=$ 


\section{TABLE 7}

Student Research Skills and Practices: Undergraduate and Graduate $(N=425)$ My students are able to conceptualize and formulate good questions.

\begin{tabular}{|l|c|c|c|c|c|c|c|c|c|l|}
\hline & $\begin{array}{c}\text { Valid } \\
\text { N }\end{array}$ & All & Most & Some & Few & None & N/A & $\begin{array}{c}\text { Cannot } \\
\text { Judge }\end{array}$ & STD & Mean \\
\hline Ugrad & 416 & $2.4 \%$ & $34.1 \%$ & $54.1 \%$ & $9.1 \%$ & $0.2 \%$ & $0.0 \%$ & $0.0 \%$ & 0.673 & 2.71 \\
\hline Grad & 297 & $7.1 \%$ & $65.0 \%$ & $25.9 \%$ & $1.7 \%$ & $0.3 \%$ & $0.0 \%$ & $0.0 \%$ & 0.612 & 2.23 \\
\hline
\end{tabular}

My students display sound critical thinking skills.

\begin{tabular}{|l|l|l|l|l|l|l|l|l|l|l|} 
& $\begin{array}{c}\text { Valid } \\
\text { N }\end{array}$ & All & Most & Some & Few & None & N/A & $\begin{array}{c}\text { Cannot } \\
\text { Judge }\end{array}$ & STD & Mean \\
\hline Ugrad & 415 & $1.9 \%$ & $30.1 \%$ & $53.3 \%$ & $14.7 \%$ & $0.0 \%$ & $0.0 \%$ & $0.0 \%$ & 0.7 & 2.81 \\
\hline Grad & 299 & $5.4 \%$ & $68.2 \%$ & $24.1 \%$ & $2.0 \%$ & $0.3 \%$ & $0.0 \%$ & $0.0 \%$ & 0.591 & 2.24 \\
\hline
\end{tabular}

My students apply analysis and original thought to existing information to create new information.

\begin{tabular}{|l|l|l|l|l|l|l|l|l|l|l|}
\hline & $\begin{array}{c}\text { Valid } \\
\text { N }\end{array}$ & All & Most & Some & Few & None & N/A & $\begin{array}{c}\text { Cannot } \\
\text { Judge }\end{array}$ & STD & Mean \\
\hline Ugrad & 418 & $1.7 \%$ & $18.2 \%$ & $47.6 \%$ & $28.9 \%$ & $1.4 \%$ & $0.7 \%$ & $1.4 \%$ & 0.927 & 3.18 \\
\hline Grad & 332 & $3.3 \%$ & $41.9 \%$ & $38.6 \%$ & $4.2 \%$ & $0.0 \%$ & $9.9 \%$ & $2.1 \%$ & 1.352 & 2.94 \\
\hline
\end{tabular}

My students have an understanding of how information is produced, organized, and disseminated.

\begin{tabular}{|l|c|c|c|c|c|c|c|c|c|l|}
\hline & $\begin{array}{c}\text { Valid } \\
\mathbf{N}\end{array}$ & All & Most & Some & Few & None & N/A & $\begin{array}{c}\text { Cannot } \\
\text { Judge }\end{array}$ & STD & Mean \\
\hline Ugrad & 416 & $6.7 \%$ & $31.7 \%$ & $39.2 \%$ & $18.3 \%$ & $1.0 \%$ & $0.5 \%$ & $2.6 \%$ & 1.123 & 2.87 \\
\hline Grad & 351 & $10.0 \%$ & $47.0 \%$ & $20.8 \%$ & $4.6 \%$ & $13.7 \%$ & $4.0 \%$ & $0.0 \%$ & 1.67 & 2.95 \\
\hline
\end{tabular}

My students have an understanding of how information is organized into disciplines and subject fields.

\begin{tabular}{|l|c|c|c|c|c|c|c|c|c|l|}
\hline & $\begin{array}{c}\text { Valid } \\
\mathbf{N}\end{array}$ & All & Most & Some & Few & None & N/A & $\begin{array}{c}\text { Cannot } \\
\text { Judge }\end{array}$ & STD & Mean \\
\hline Ugrad & 416 & $4.6 \%$ & $23.8 \%$ & $37.3 \%$ & $24.5 \%$ & $1.7 \%$ & $0.5 \%$ & $7.7 \%$ & 1.392 & 3.27 \\
\hline Grad & 351 & $9.7 \%$ & $41.0 \%$ & $24.8 \%$ & $5.4 \%$ & $13.1 \%$ & $6.0 \%$ & $0.0 \%$ & 1.729 & 3.08 \\
\hline
\end{tabular}

My students understand how professionals working in their area of study use information.

\begin{tabular}{|l|l|l|l|l|l|l|l|l|l|l|}
\hline & $\begin{array}{c}\text { Valid } \\
\mathbf{N}\end{array}$ & All & Most & Some & Few & None & N/A & $\begin{array}{c}\text { Cannot } \\
\text { Judge }\end{array}$ & STD & Mean \\
\hline Ugrad & 416 & $7.9 \%$ & $31.7 \%$ & $40.1 \%$ & $15.9 \%$ & $1.2 \%$ & $0.5 \%$ & $2.6 \%$ & 1.132 & 2.83 \\
\hline Grad & 351 & $13.4 \%$ & $45.9 \%$ & $20.8 \%$ & $3.4 \%$ & $0.3 \%$ & $13.7 \%$ & $2.6 \%$ & 1.63 & 2.83 \\
\hline
\end{tabular}

My students confer with faculty to identify information resources and processes used in the field.

\begin{tabular}{|l|l|l|l|l|l|l|l|l|l|l|}
\hline & $\begin{array}{c}\text { Valid } \\
\text { N }\end{array}$ & All & Most & Some & Few & None & N/A & $\begin{array}{c}\text { Cannot } \\
\text { Judge }\end{array}$ & STD & Mean \\
\hline Ugrad & 415 & $6.3 \%$ & $24.8 \%$ & $40.2 \%$ & $23.6 \%$ & $1.7 \%$ & $0.7 \%$ & $2.7 \%$ & 1.138 & 3.02 \\
\hline Grad & 351 & $14.8 \%$ & $41.9 \%$ & $22.8 \%$ & $3.4 \%$ & $0.6 \%$ & $13.7 \%$ & $2.8 \%$ & 1.656 & 2.85 \\
\hline
\end{tabular}


TABLE 7

Student Research Skills and Practices: Undergraduate and Graduate $(\mathrm{N}=425)$

My students understand that research is a strategic process and approach it as such.

\begin{tabular}{|l|c|l|l|l|l|l|l|l|l|l|}
\hline & $\begin{array}{c}\text { Valid } \\
\mathbf{N}\end{array}$ & All & Most & Some & Few & None & N/A & $\begin{array}{c}\text { Cannot } \\
\text { Judge }\end{array}$ & STD & Mean \\
\hline Ugrad & 415 & $4.3 \%$ & $21.4 \%$ & $28.9 \%$ & $35.7 \%$ & $3.1 \%$ & $1.0 \%$ & $5.5 \%$ & 1.308 & 3.37 \\
\hline Grad & 348 & $11.5 \%$ & $36.8 \%$ & $29.0 \%$ & $3.4 \%$ & $0.6 \%$ & $13.5 \%$ & $5.2 \%$ & 1.713 & 3.06 \\
\hline
\end{tabular}

My students know that research methodologies vary and apply the appropriate method as necessary.

\begin{tabular}{|l|l|l|l|l|l|l|l|l|l|l|}
\hline & $\begin{array}{c}\text { Valid } \\
\mathbf{N}\end{array}$ & All & Most & Some & Few & None & N/A & $\begin{array}{c}\text { Cannot } \\
\text { Judge }\end{array}$ & STD & Mean \\
\hline Ugrad & 414 & $2.9 \%$ & $14.3 \%$ & $33.6 \%$ & $34.8 \%$ & $4.8 \%$ & $2.9 \%$ & $6.8 \%$ & 1.336 & 3.6 \\
\hline Grad & 351 & $12.3 \%$ & $38.2 \%$ & $26.8 \%$ & $4.0 \%$ & $0.9 \%$ & $14.0 \%$ & $4.0 \%$ & 1.688 & 3.01 \\
\hline
\end{tabular}

My students know where to find data and information in traditional print reference resources.

\begin{tabular}{|l|c|c|c|c|c|c|c|c|c|l|}
\hline & $\begin{array}{c}\text { Valid } \\
\mathbf{N}\end{array}$ & All & Most & Some & Few & None & N/A & $\begin{array}{c}\text { Cannot } \\
\text { Judge }\end{array}$ & STD & Mean \\
\hline Ugrad & 417 & $2.9 \%$ & $29.7 \%$ & $39.8 \%$ & $21.3 \%$ & $2.2 \%$ & $1.0 \%$ & $3.1 \%$ & 1.139 & 3.06 \\
\hline Grad & 352 & $9.7 \%$ & $42.9 \%$ & $25.9 \%$ & $5.4 \%$ & $0.3 \%$ & $13.6 \%$ & $2.3 \%$ & 1.573 & 2.94 \\
\hline
\end{tabular}

My students know how to find data and information in electronic databases and on the World Wide Web.

\begin{tabular}{|l|l|l|l|l|l|l|l|l|l|l|}
\hline & $\begin{array}{l}\text { Valid } \\
\text { N }\end{array}$ & All & Most & Some & Few & None & N/A & $\begin{array}{l}\text { Cannot } \\
\text { Judge }\end{array}$ & STD & Mean \\
\hline Ugrad & 417 & $15.8 \%$ & $53.5 \%$ & $23.3 \%$ & $5.8 \%$ & $0.0 \%$ & $0.5 \%$ & $1.2 \%$ & 0.963 & 2.27 \\
\hline Grad & 352 & $24.1 \%$ & $50.3 \%$ & $9.1 \%$ & $1.7 \%$ & $0.0 \%$ & $13.4 \%$ & $1.4 \%$ & 1.631 & 2.49 \\
\hline
\end{tabular}

My students are able to apply evaluative criteria to, and select quality information from, the World Wide Web.

\begin{tabular}{|l|c|c|c|c|c|c|c|c|c|l|}
\hline & $\begin{array}{c}\text { Valid } \\
\text { N }\end{array}$ & All & Most & Some & Few & None & N/A & $\begin{array}{c}\text { Cannot } \\
\text { Judge }\end{array}$ & STD & Mean \\
\hline Ugrad & 417 & $3.1 \%$ & $22.3 \%$ & $45.8 \%$ & $23.3 \%$ & $2.6 \%$ & $0.7 \%$ & $2.2 \%$ & 1.043 & 3.11 \\
\hline Grad & 352 & $5.1 \%$ & $41.8 \%$ & $33.0 \%$ & $4.0 \%$ & $13.6 \%$ & $2.6 \%$ & $0.0 \%$ & 1.518 & 3.03 \\
\hline My students can discriminate between scholarly and nonscholarly information resources. \\
\hline \\
\begin{tabular}{|l|c|c|c|c|c|c|c|c|} 
Valid \\
$\mathbf{N}$
\end{tabular} & All & Most & Some & Few & None & N/A & $\begin{array}{c}\text { Cannot } \\
\text { Judge }\end{array}$ & STD & Mean \\
\hline Ugrad & 417 & $3.8 \%$ & $16.3 \%$ & $37.6 \%$ & $32.9 \%$ & $4.8 \%$ & $1.2 \%$ & $3.4 \%$ & 1.166 & 3.35 \\
\hline Grad & 351 & $15.4 \%$ & $46.2 \%$ & $18.5 \%$ & $2.3 \%$ & $0.0 \%$ & $14.0 \%$ & $3.7 \%$ & 1.71 & 2.82 \\
\hline
\end{tabular}

425) responded, with thirty-four $(9.2 \% ; n=$ 371) stating their students' research skills were excellent. The greatest number of faculty reported their graduate students' research skills were adequate $(122 ; 32.9 \%$; $\mathrm{n}=371$ ). A similar cross-tabulation was done on the responses to this statement and the report on the frequency of library instruction for faculty teaching graduate students. It was found that faculty who reported their students' skills to be adequate made library instruction a regular part of their courses to some degree more frequently than those faculty members 


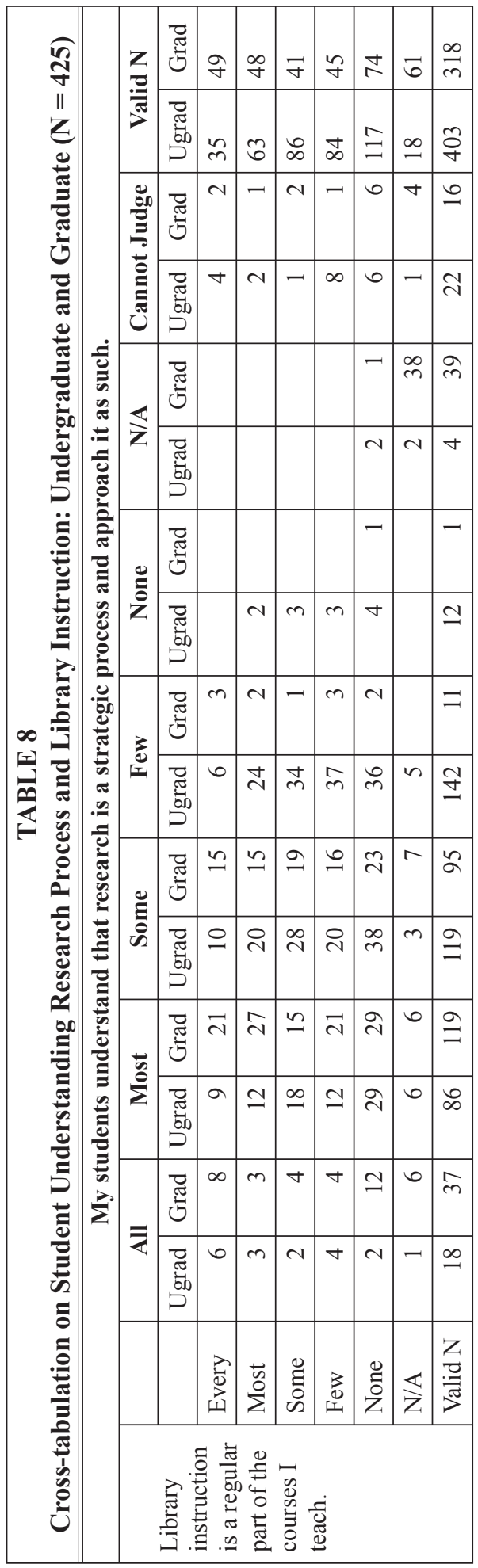

who estimated their students' research skills otherwise. (See table 11.)

To assess whether faculty members' concepts of excellent research skills were in line with the core competencies of information literacy as articulated by the ACRL standards, correlations were generated on these two variables that were significant: $r-.666 ; \mathrm{Q}=.684$ for undergraduate scores; $r-.882 ; \mathrm{Q}=.808$ for graduate scores. A cross-tabulation of the two statements was done showing that four of the seven faculty teaching undergraduates (57\%) who categorized the research skills of their students as excellent also stated their students met all of the ACRL criteria for information literacy. Fifty-two who reported their students' research skills were strong said they met most of the ACRL criteria.

For graduate students, thirteen of the thirty-two faculty members $(40.6 \%)$ who stated their students' research skills were excellent also reported they met all the ACRL base competencies. The highest numbers in the excellent and strong categories for graduate students' research skills, seventeen and eightyfour, respectively, were from faculty who stated their students met most of the ACRL criteria. Given that for all faculty responding to these statements roughly 75 percent stated that strong research skills met most of the ACRL criteria, one could infer that the ACRL definition satisfied some faculties' concepts of excellent research skills, but this should be clarified by more specific questioning and, again, presents an area for further research. (See table 12.)

\section{Discussion}

The purpose of this study was to assess the perceptions that faculty teaching in journalism and mass communication programs accredited by the ACEJMC have of their students' information literacy skills and to ascertain the frequency and impact of library instruction on their students' research. Analysis of the data has revealed some 


\begin{tabular}{|c|c|c|c|c|c|c|c|c|c|}
\hline \multicolumn{10}{|c|}{$\begin{array}{c}\text { TABLE } 9 \\
\text { Frequency of Faculty Reporting on Info. Lit. Competency and Research } \\
\text { Skills: Undergraduate and Graduate }(\mathrm{N}=425)\end{array}$} \\
\hline \multicolumn{3}{|c|}{$\begin{array}{c}\text { Info. Literacy } \\
\text { Competency }\end{array}$} & \multicolumn{3}{|c|}{ Research Skills } & \multicolumn{4}{|c|}{ Standard Deviation } \\
\hline & \multicolumn{2}{|c|}{$\begin{array}{c}\text { Frequency / } \\
\% \text { No. }\end{array}$} & & \multicolumn{2}{|c|}{$\begin{array}{c}\text { Frequency/ } \\
\% \text { No. }\end{array}$} & \multicolumn{2}{|c|}{$\begin{array}{l}\text { Info. Lit. } \\
\text { Competency }\end{array}$} & \multicolumn{2}{|c|}{ Res. Skills } \\
\hline & Ugrad & Grad & & Ugrad & Grad & Ugrad & Grad & Ugrad & Grad \\
\hline All & $\begin{array}{l}16 / \\
3.8\end{array}$ & $\begin{array}{l}33 / \\
9.1 \\
\end{array}$ & Excellent & $\begin{array}{l}7 / \\
1.7\end{array}$ & $\begin{array}{l}34 / \\
9.2\end{array}$ & .985 & 1.709 & .797 & 1.352 \\
\hline Most & $\begin{array}{l}116 / \\
27.7\end{array}$ & $\begin{array}{l}160 / \\
44.2\end{array}$ & Strong & $\begin{array}{l}69 / \\
16.5\end{array}$ & $\begin{array}{l}114 / \\
30.7\end{array}$ & & & & \\
\hline Some & $\begin{array}{l}177 / \\
42.2\end{array}$ & $\begin{array}{l}85 / \\
23.5\end{array}$ & Adequate & $\begin{array}{l}194 / \\
46.5\end{array}$ & $\begin{array}{l}122 / \\
32.9\end{array}$ & \multicolumn{4}{|c|}{ Mean } \\
\hline Few & $\begin{array}{l}98 / \\
23.4\end{array}$ & $\begin{array}{l}8 / \\
2.2\end{array}$ & Poor & $\begin{array}{l}141 / \\
33.8\end{array}$ & $\begin{array}{c}24 / \\
6.5\end{array}$ & \multicolumn{2}{|c|}{$\begin{array}{c}\text { Info. Lit. } \\
\text { Competency }\end{array}$} & \multicolumn{2}{|c|}{ Res. Skills } \\
\hline None & $3 / .7$ & $1 / .3$ & $\mathrm{~N} / \mathrm{A}$ & $\begin{array}{r}3 / \\
.7\end{array}$ & $\begin{array}{l}58 / \\
15.6\end{array}$ & Ugrad & Grad & Ugrad & Grad \\
\hline N/A & $4 / 1$ & $\begin{array}{c}64 / \\
7.7\end{array}$ & $\begin{array}{l}\text { Cannot } \\
\text { Judge }\end{array}$ & $\begin{array}{r}3 / \\
.7\end{array}$ & $\begin{array}{c}19 / \\
5.1\end{array}$ & 2.97 & 3.06 & 3.18 & 3.04 \\
\hline $\begin{array}{l}\text { Cannot } \\
\text { Judge }\end{array}$ & $5 / 1.2$ & $11 / 3$ & & & & & & & \\
\hline Valid N & 419 & 362 & Valid N & 417 & 371 & & & & \\
\hline
\end{tabular}

interesting results that warrant closer examination.

- The most frequent response to the question, "Assignments requiring library research are a regular part of the courses I teach," was "every," whereas the most frequent response to the question, "Library instruction is a regular part of the courses I teach," was "none," from faculty teaching both undergraduate and graduate students. (See table 2.)

- The greatest number of faculty reporting they knew their library had in place a model for specialized curricular support were those faculty who reported they did not make library instruction a regular part of "any" of their courses. (This is true for faculty teaching both undergraduate and graduate students.) (See table 5.)

- The most frequent response to the statement, "I have included library instruction in my courses in the past and found it improved/made no difference/ confused my students' understanding of the research process," was "improved" for faculty teaching both undergraduate and graduate students. (See table 4.)

- Only four faculty $(.96 \% ; n=416)$ teaching undergraduates characterized their students as meeting all of the ACRL standards for being information literate and as having "excellent" research skills. Thirteen faculty $(3.63 \%$; $N=358)$ teaching graduate students characterized their students the same way. (See Table 12.)

- The percentage of faculty reporting "all" of their students could be characterized by the statements on research skills and practices (table 7) was never higher than 10 percent for undergraduate students (except in the case of ability to find information in electronic databases and on the Web, for which it was $15.8 \%$ ) and 15 percent for graduate students (again, except in the case of ability to find infor- 
Faculty Perceptions of Students' Information Literacy Competencies 307

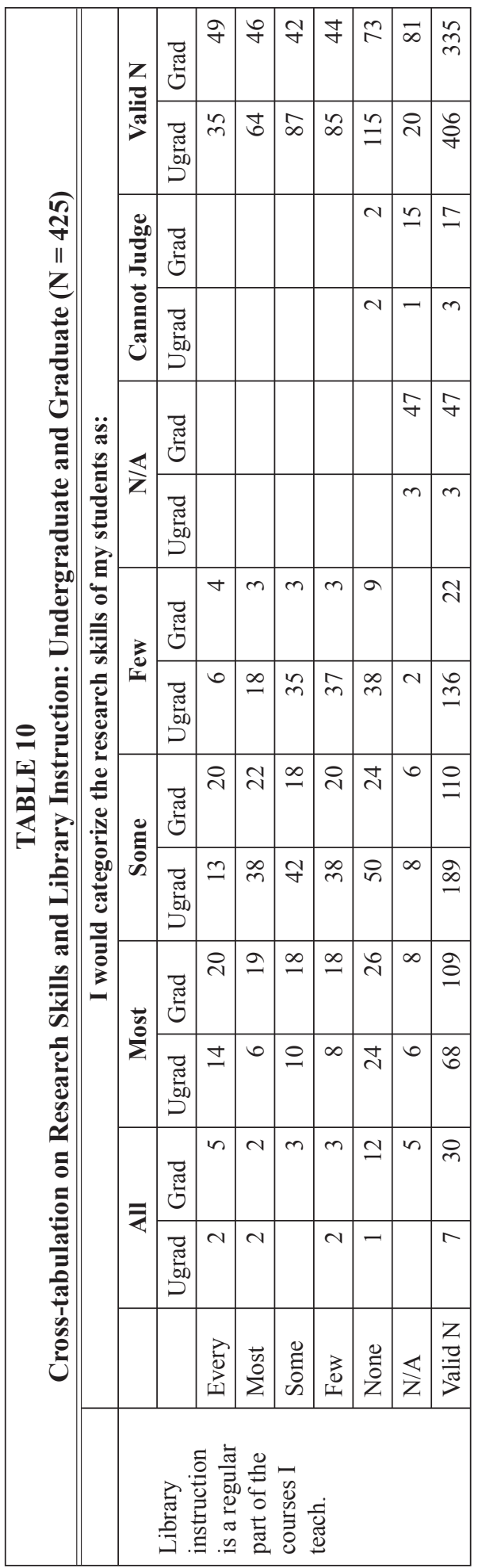

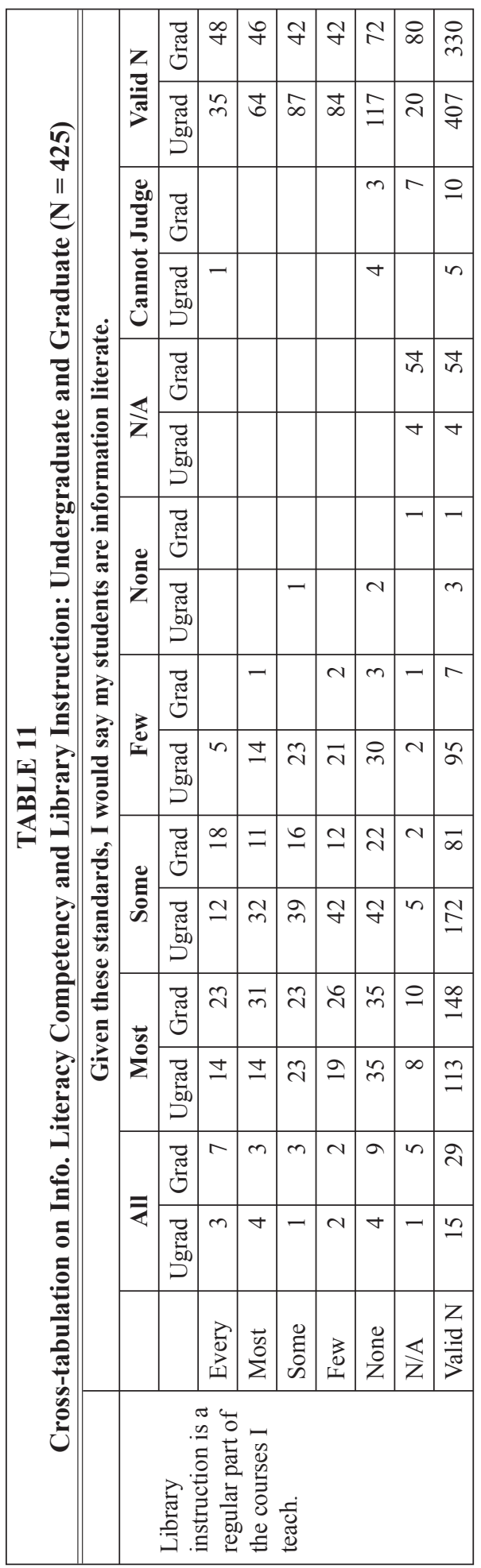




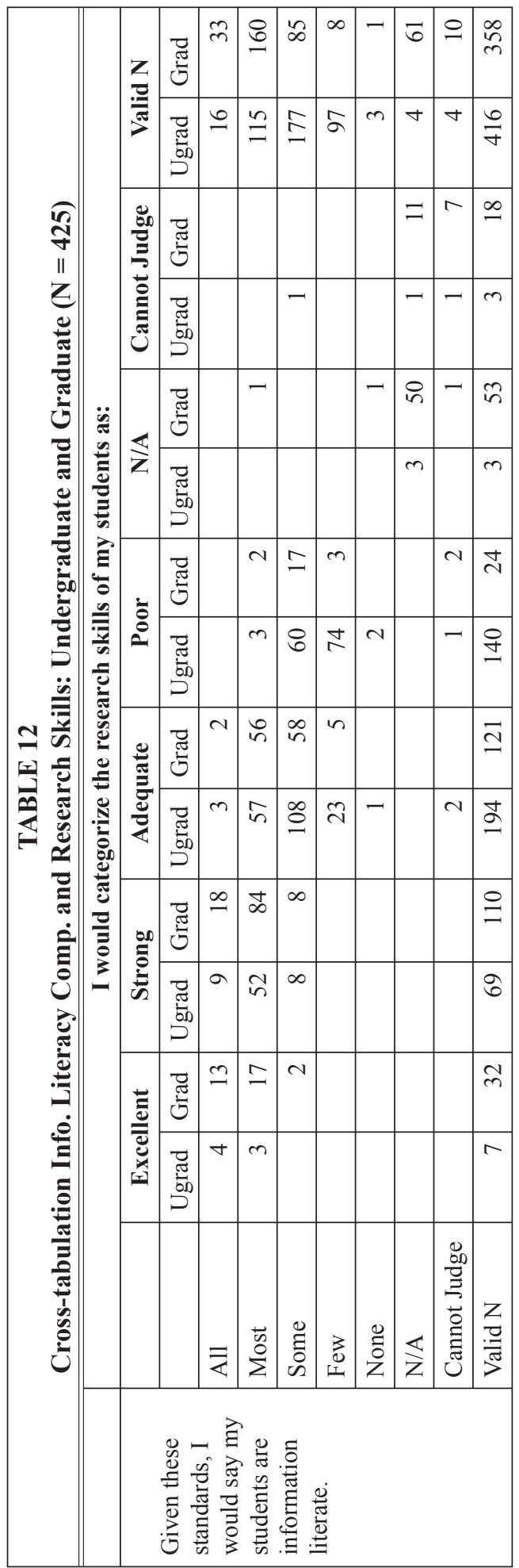

mation in electronic databases and on the Web, for which it was $24.1 \%$ ).

These outcomes present a picture that raises several questions or perhaps just one big one: Given that faculty make assignments that require library research a regular part of their courses, know that library instruction improves students' research skills, see that their students are not as information literate as they could be, recognize that their students have research skills and practices that need improvement, and understand that their university library is structured to provide specialized research instruction, why is library instruction not integrated in a consistent and intentional manner into the courses being taught in these JMC programs at a greater rate?

Integration of information literacy education into a curriculum is "most successful when strategies are developed within the philosophy of academic administrations - information literacy should be a part of the academic mandate of the institution." ${ }^{\prime 9}$ A variety of factors drive institutional and curricular change; one among them is accreditation. Regional accreditation commissions for higher education across the country are stating unambiguously that students should be "required" to use library and information resources or that the university/college "ensures that users have access to regular and timely instruction in the use of the library and other learning/information resources." 10 The strongest advocate of information literacy has been the Middle States Commission on Higher Education, whose definition of information literacy strikingly parallels that of ACRL:

[information literacy is] an intellectual framework for identifying, finding, understanding, evaluating and using information. It 
includes determining the nature and extent of needed information; accessing information effectively and efficiently; evaluating critically information and its sources; incorporating selected information in the learner's knowledge base and value system; using information effectively to accomplish a specific purpose; understanding the economic, legal and social issues surrounding the use of information and information technology; and observing laws, regulations, and institutional policies related to the access and use of information. ${ }^{11}$

In 2003, Middle States published Developing Research \& Communication Skills: Guidelines for Information Literacy in the Curriculum, providing strategies upon which institutions may plan a course of action for integration of information literacy across the curriculum. Driving change on the programmatic level for JMC curricula, the ACEJMC states in standard 2 of its Standards of Accreditation that the educational unit must provide "a curriculum and instruction that enable students to learn the knowledge, competencies and values the Council defines for preparing students to work in diverse global and domestic society."12 Two of the competencies delineated are the ability to "think critically, creatively and independently" and "conduct research and evaluate information by methods appropriate to the communications professions in which they work." ${ }^{13}$ The ACRL standards provide a framework within which librarians and JMC faculty can work together to further refine a vision of an information-literate JMC student and build a curriculum within which information literacy education is fundamental.

\section{Conclusion}

In her 1996 report, "Winds of Change: Challenges Confronting Journalism Education," Betty Medsger stated:

Be it heavy and important or light and easy, [journalism] is an intellectual process. Whether executed masterfully or superficially or shoddily, it is, nevertheless, a process of critical thinking and decision-making. The well-trained journalist's mind inquires, weaves, thinks again, unravels, asks again, corrects, goes back again, weaves again.... Students enter the journalism classroom often looking for a formula. Instead, they are asked to think-carefully, critically, precisely - and to do so beyond their own interests, to think of the public's interests and needs. ${ }^{14}$

JMC faculty and librarians are obligated to train JMC students to be information literate. Mandates emanate from professional associations and accrediting agencies, but it is not only these directives that compel them. It is the "goodness of fit" of information literacy skills with the professional expertise anticipated of JMC students that makes for a complimentary relationship, the development of which is the responsibility of institution administrations, JMC faculty and librarians, and that promises a better-educated student and informed citizenry.

\section{Notes}

1. Accrediting Council on Education in Journalism and Mass Communications, ACEJMC Standards of Accreditation (Sept. 2003). Available online from http://www.ukans.edu/ acejmc/ BREAKING/New_standards_9-03.pdf [cited 6 May 2004].

2. Ibid., 9.

3. Project on the Future of Journalism and Mass Communication Education, Planning for Curricular Change: A Report of the Project on the Future of Journalism and Mass Communication Education, 2nd ed. (Eugene: University of Oregon, School of Journalism, 1987), 51. 
4. Betty Medsger, Winds of Change: Challenges Confronting Journalism Education (Arlington, Va.: The Freedom Forum, 1996), 11-12.

5. Ann Grafstein, "A Discipline-based Approach to Information Literacy," Journal of Academic Librarianship 28, no. 4 (2002): 197.

6. Association of College and Research Libraries, Information Literacy Competency Standards for Higher Education (Chicago: ACRL), 2-3.

7. Ibid., 3.

8. Ibid.

9. Deborah V. Dolan and Georgina Martorella, "Discipline-based Information Literacy and the Lifelong Learner," International Journal of Learning 10 (2003): 1330.

10. Gary B. Thompson, "Information Literacy Accreditation Mandates: What They Mean for Faculty and Librarians," Library Trends 51 (fall 2002): 221.

11. Middle States Commission on Higher Education, Developing Research \& Communication Skills: Guidelines for Information Literacy in the Curriculum (Philadelphia: MSCHE, 2003), 1.

12. Accrediting Council on Education in Journalism and Mass Communications, ACEJMC Standards of Accreditation.

13. Ibid.

14. Medsger, Winds of Change, 9 . 


\section{News \& Notes on Haworth Library \& Information Science Journals}

> Announcing new journal editors

> Announcing new journals off press

- Complimentary sample copies available

\section{The Acquisitions Librarian ${ }^{\mathrm{TM}}$}

Interin Edtor SUl H. Low, Den of Unw craty Ltranes.

The Urhersty of Cldihoma, Noman

Founding Edtor: Bill Kalz idcoused], Profisser, school

of hicamaion Sdence and Pollcy, Nabcon A. Boclefilks

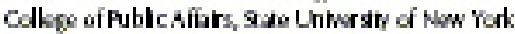

at Albarm

\section{College \& Undergraduate Libraries ${ }^{\mathrm{TM}}$}

Under naw aditorstp begiesing witb Wol i3, spring 2006

Bdicr-Eled: Chrisopher Millon-Manda Dreacr of the

Ltriry, Lynatbug Colkge, Lynatue, Mrginis

\section{Internet Reference}

Services Quarterly ${ }^{\mathrm{TM}}$

a journal of imonative information practios,

technologies, and resources

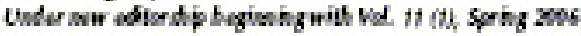

Edver-Eled: Chritopher N. Cox Asture Próiser.

Untrersty ofWlsconein, Eau Clare

\section{Journal of Access Services ${ }^{\mathrm{TM}}$}

imnorations for Electronic and

Digital Libaryand Information Resources

Under naw aditar to begiesieg witb Wal 3 (1) Sprieg 2005

Edver: Dwid Pena PhD, Hed of Acoess Services,

Fkndastartic Untwersity, Bcca Raken, Fbnda

\section{Journal of Business}

\section{\& Finance Librarianship ${ }^{\text {w }}$}

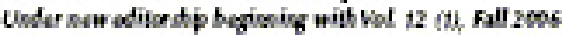

Edver-ded: Cry W.Whte, MIS, MBA, Had.

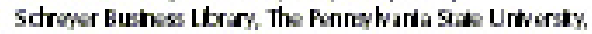

Untrersty Parl:

\section{Journal of Consumer Health}

\section{on the Internet ${ }^{\text {tw }}$}

Under sede adiontip bygionég witb bL 1031 , Sprieg 2006 Edver: M. Sanda Wood, MIS, NBA, AHIP, FMLA, L trarian, Deikrence and Duabuse Services, The Cocnge T. Hanell Lteriry, The Miton S. Hershy Madicil Conter,

The Penneytrarda Sake Untrersty, Horshey

- Docrici jaimal drors, go to www.HuwontPessocmiaumakjodsearch asp

- To recpes samale coples of karnds, email onderse Hewontfressicom or ind the pumal in carr Qudseach orline cadidog and order a complmentry sample copy

- Orline wooss is walbkle wh prin suberkikn

- D rectiecar bab-ofoctens emal sarvice complesewith abaradsi go bo www. HawontPwssucomioc

\section{Journal of Electronic}

Resources in Medical Libraries ${ }^{\mathrm{TM}}$

Edtor: M SandraWood MIS, MBA, AHP, FMLA, Ltrian, Fofenence and Databese Servos, Cacre T. Herell utrary, The Muton S. Hershey Madical Cerex, The Pernsytuaria

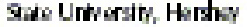

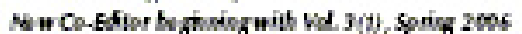
CoEdtor: Elzabeth Corner, MLS, AHP, Assigiar Profiesser of utrary Sdence, The Cridst, Denbl utrary, Gharkson, Souh Caclin:

\section{The Reference Librarian ${ }^{\mathrm{TM}}$}

hicrim Ediex: sul $\mathrm{H}$ Les, Dean of Unmerdy Ltrides, The Untorsty of Ollabema Norman

Former Edtor: all Kar ideceased. Prefessor, school of Informaicn Scianoe and Pelic, Nilsona. Dodafelkr Colbe of Putlic Afidrs, Sade Untersty of New York albery

\section{FORTHCOWMNG JOURNALS}

\section{Journal of Electronic}

\section{Resources in Law Libraries"}

Edtor: barne Fader Price, JD, MIS, Dredor of haruabnal Services, Taricon Liw Ltrary, The Unweraty of Texas Schod of $\mathrm{L} w$, Ausin

Fra Irwe Arib He Sprigg $200 \mathrm{~s}$

Journal of the

\section{Infernet in Technical Services ${ }^{\text {"* }}$}

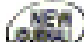

Edtor: Mante Husla, MIS, Drockr, Rdholky Services

Dwiston, Cacreas. Smahrs Ltriks, Urwersy offlerida, Cednesille

Fro Irwe Anaib He Sprige 2005

\section{Library \& Information Professionalst}

Visit Hawortrs Web stee for litrarlans orly bo read colums on impertant lbrary and informadion sdence kaplos.

www.HaworihPress comlibrary/columns.as $p$ Selectod columrs from Haworth's proksstonal joumds appeir, such is "The Serids Report," a regular column from The Serials Librarian by Bearke L. Garaway.

Youtl abo find a columnw ritten espendalty for the Web stk: "Slywritings: Schdirly and Lesurely," an cociesiond column by archrraredist Sewan Hamid. Ganida Reseirch Chair in Cognitre Scknces at the uriversité du Qusbec a Monirsal. 